\title{
Determinants of farmers' adaptation decisions to climate change in the central coastal region of Vietnam
}

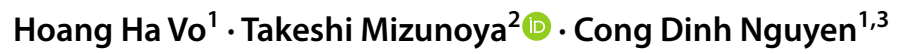

Received: 23 March 2020 / Accepted: 11 November 2020 / Published online: 2 January 2021

(c) The Author(s) 2021

\begin{abstract}
This study examined measures and factors influencing the climate change adaptation decisions of smallholder farmers holding less than 0.5 hectares of farmland. The binary logit model was applied to analyze data collected by face-to-face interviews with 110 households in Phu Vang Coastal District, Thua Thien Hue Province, Central Vietnam. The findings indicate that most farmers accurately perceived climate-related changes during the recent decade, and implemented various adaptation measures in an effort to alleviate the potential risks. Adaptations included changing crop varieties, adjusting farming calendar, diversifying crops, diversifying livestock, improving irrigation, and intensifying soil quality. In addition, the farming household adaptation decisions were positively affected by gender, education level, number of laborers, income level, involvement in local community organizations, and perception of climate change severity and adaptation measure efficacy. Farmer adaptations, in contrast, were negatively influenced by non-farm income and entirely unaffected by access to credit. Policy-related recommendations were proposed to encourage smallholder farmers to adapt to climate change in the region. Recommendations included (1) improvements in the understanding of climate change, especially for female and less educated farmers; (2) more attention paid to the activities of local community organizations to be more attractive for members; (3) participation in the non-agricultural sector in parallel with implementing climate change adaptation measures in agriculture; (4) preferential loans designed as targets for low-income households combined with strict management to avoid misuse by beneficiaries.
\end{abstract}

Keywords Climate change $\cdot$ Smallholder farmers $\cdot$ Adaptation decision $\cdot$ Phu Vang district $\cdot$ Central Vietnam

JEL Classification C52 $\cdot \mathrm{Q} 10 \cdot \mathrm{Q} 15 \cdot \mathrm{Q} 18 \cdot \mathrm{Q} 54$

Takeshi Mizunoya

mizunoya.takeshi.ff@u.tsukuba.ac.jp

Extended author information available on the last page of the article 


\section{Introduction}

Climate change is widely recognized as one of the biggest challenges in modern society (IPCC 2014). The increasing concentration of greenhouse gases has increased the average temperature, altered the amount and distribution of precipitation globally (IPCC 2018). According to the Intergovernmental Panel on Climate Change, the global mean surface temperature changes for the period 2016-2035, similar to the period 1986-2005, will likely be in the range 0.3 to $0.7{ }^{\circ} \mathrm{C}$ but is projected to likely exceed $1.5{ }^{\circ} \mathrm{C}$ by the end of the twenty-first century (IPCC 2013). The increasing popularity of floods, droughts, and other extreme climatic phenomena was anticipated as an inevitable consequence of these variations (Coumou and Rahmstorf 2012; Hatfield et al. 2011).

As a country intensely susceptible to the changes of climate, Vietnam was ranked sixth among the countries most severely influenced by extreme weather events in the last two decades (Eckstein et al. 2019). This reality probably stems from its geographical characteristics associated with the monsoon climate, but also seems to be getting worse under the negative effects of global climate change. The annual average temperature in Vietnam has increased by about $0.5-0.7{ }^{\circ} \mathrm{C}$ since the $1960 \mathrm{~s}$ and is predicted to be increased by $1.1-1.8^{\circ} \mathrm{C}$ by 2050 (World Bank 2016). The sea-water level, similarly, is anticipated to rise $17 \mathrm{~cm}$ by 2030 , and $30 \mathrm{~cm}$ by 2050 (MONRE 2009).

Despite the ongoing process of industrialization in Vietnam, agriculture still plays an important and inseparable component of the economy, which substantially contributes to poverty reduction, food security, as well as socio-political stability. As one of the biggest rice exporters in the world with approximately 4 million tons per year, Vietnam graded fifth among the 15 countries that achieved the highest revenue from rice exports with 1.7 billion USD in 2017 (WTO 2018). Currently, agriculture contributes $15.34 \%$ to GDP and creates the working environments for about $40 \%$ of the total employees (GSO 2018). In many places, however, the efficiency of agricultural production in recent decades has seriously threatened due to the increasing popularity of extreme climatic phenomena (Irish Aid 2017). The crop yield was decreased by 7.5-19.1\% in the Red River Delta, and $4.3-8.3 \%$ in the Mekong River Delta (Yu et al. 2010), which threatens the national food security.

It is apparent that agriculture is one of the most vulnerable sectors in the context of changing climate (Parry et al. 2005). The smallholder farmers in developing countries, who largely rely on rainfed agricultural livelihoods, are seen as the most severely affected (Bankoff 1999). Adaptation appears as the most efficient and friendly approach to minimize the adverse impacts of climate change (Fussel and Klein 2006). Without effective adaptation, initial climate change related concerns could translate into severe consequences in relation to the welfare of a substantial number of people in the developing world (Nelson et al. 2009; IPCC 2014).

According to IPCC (2014), climate change adaptation refers to the adjustment in natural or human systems to respond to actual or anticipated climatic stimuli, 
and its effects, which alleviates damages or exploits beneficial opportunities. Adaptation measures can be implemented at different levels such as by individual households, groups, or communities. However, these are generally inadequate and thus require appropriate interventions of various institutions to encourage the adaptation process (Simane et al. 2016). In this regard, the comprehensive understanding of area-specific opportunities, challenges, as well as determining factors standing behind farmers' adaptation decisions should be a prerequisite.

Some previous studies indicated that adjusting planting dates, using highly resistant crop varieties, practicing soil conservation techniques, intensifying fertilizer, improving irrigation, and engaging in non-farm activities are the most well-known adaptation strategies by small-scale farmers (Alam et al. 2017; Mideksa 2010; Bryan et al. 2009; Menike and Arachchi 2016; Tesfaye and Seifu 2016). Adaptation decisions, however, are location-specific and thus may be influenced by different key drivers. A number of studies conducted in different contexts and regions in developing countries reported factors influencing farmers' adaptation. These include demographic, socio-economic characteristics (Deressa et al. 2009; Hisali et al. 2011); perception of climate change (Patt and Schro 2008; Vedwan and Rhoades 2001); knowledge and information (Gbetibouo et al. 2010); and psychological factors (Grothmann and Patt 2005).

Several studies on the same topic were also conducted in the specific conditions of Vietnam. Key factors driving farmers' adaptation decisions, hence, were revealed such as socio-demographic features (Mishra and Pede 2017; Thanh 2016; Thoai et al. 2018), risk perception (Dang et al. 2014; Luu et al. 2019), social capital (Nam 2011), or geographical location (Waibel et al. 2018; Ho and Shimada 2019). However, there are relatively few studies, especially in central Vietnam, that consider how perceptions of climate change severity and adaptation measure efficacy affect farmers' adaptation decision. This study, therefore, attempts to fill this dearth of knowledge by investigating the adaptation decision of smallholder farmers in central coast region of Vietnam in relation to their socio-demographic characteristics, and perceptions of climate change severity and adaptation measure efficacy.

This study is expected to reveal both encouraging and hindering factors behind farmers' adaptation, and its finding may be useful for the local policymakers to design interventions promoting climate change adaptation.

\section{Literature review}

A number of studies have been undertaken in different regions worldwide to investigate the influence of various factors on farmers' adaptation. Since climate change and adaptation are local-specific issues, the findings from these studies were also diverse.

As the pillar of families, the household head profiles are commonly used to examine the link to adaptation. While most studies indicated that male-head households are more likely to adopt adaptation measures (Thoai et al. 2018; Thanh 2016; Asrat and Simane 2018; Mogomotsi et al. 2020), others argue on the contrary (Tenge et al. 2004). Having fewer opportunities to access information and socio-economic 
resources, while having to bear more family burdens than males are thought to be the main reasons for this. Educational qualification was also suggested as a factor promoting adaptation of farmers (Ndamani and Watanabe 2016; Thoai et al. 2018). In this respect, Ndamani and Watanabe (2016) argued that better-educated farmers are more knowledgeable due to their ability to access information about climate change and adaptation options. Several studies further emphasized the importance of farming experience in increasing farmers' adaptation probability (Bakhsh and Kamran 2019; Thoai et al. 2018; Tessema et al. 2017; Kebede et al. 1990). In contrast, some others affirmed that the possibility of adaptation is restrained by farming experience (Shiferaw and Holden 1998; Uddin et al. 2014; Ndamani and Watanabe 2016). A possible reason is that better farming experience is often attached to elderly farmers, who generally lack interest and motivation in adapting to climate change. Regarding household resources, labor availability was usually considered an advantage to facilitate the adaptation process (Ndamani and Watanabe 2016; Asrat and Simane 2018). A study of Thoai et al. (2018), however, found no link between number of labor and adaptation. Besides, studies by Ndamani and Watanabe (2016) and Al-amin et al. (2020) indicated that household income is crucial in promoting climate change adaptation.

Similarly, the contribution of non-farm income in increasing the probability of adaptation was also disclosed by studies of Deressa et al. (2009) and Asrat and Simane (2018). In this association, they argued that a high proportion of non-farm income empowers farmers to adopt costly adaptation measures. While some studies highlighted the positive effects of access to credit on the implementation of adaptation measures (Nhemachena and Hassan 2008; Ndamani and Watanabe 2016), the results of Piya et al. (2013) disaffirmed this relationship. Misuse of funds was thought to be the first cause of this issue. Furthermore, involvement in communitybased organizations was proved to be effective in encouraging adaptation (Khanal et al. 2019). This connection, however, was negated by the conclusions of Thoai et al. (2018) and Piya et al. (2013) that membership in local organizations is worthless in increasing adaptation probability. Also, cognitive factors were included by some studies to clarify their connection to climate change adaptation. The studies by Dang et al. (2014) and Luu et al. (2019) found that adaptation probability is higher for those who are properly aware of potential risks of climate change and the efficacy of adaptation measures.

\section{Study site, data collection, and methods}

\subsection{Study site}

Thua Thien Hue Province located in the North Central Coast of Vietnam $\left(16^{\circ} 20^{\prime} \mathrm{N}\right.$ $107^{\circ} 35^{\prime} \mathrm{E}$ ) has become the target region of this study based on its geographical features, history of extreme climatic events, and anticipation of temperature and precipitation change.

With a 128-km long coastline, a dense river system, combined with 22,000 ha of the lagoon, this province is generally known as venue of different natural hazards, 
such as floods, storms, drought, deep freeze, and saline intrusion. The 1999 flood, for example, was deeply implanted in the minds of many people as a fearful memory, which took hundreds of lives and caused economic losses estimated up to millions of dollars. It is considered among the most vulnerable areas of Vietnam (Fortier 2010; Tran et al. 2008; Suu et al. 2010).

In addition, the increasing of drought and saltwater intrusion in coastal areas, which significantly hinders the locals' livelihoods, is also viewed as troubling issues in recent decades (Berchum et al. 2014). Apart from that, the climate change scenario proposed by the Ministry of Natural Resources and Environment (Thuc et al. 2016) highlighted the increasing trend in temperatures and precipitation both annually and seasonally in Thua Thien Hue Province (Table 1). Accordingly, by 2100, the average sea-level rise for the coastal areas of VietNam would be about 53-73 cm, equivalent to the inundation level of $0.93-2.59 \%$ of Thua Thien Hue Province. These facts, in combination with predictive scenarios, affirm the actuality of climate change in the province, and thus imply the necessity of taking adaptation measures.

As one of the localities most vulnerable to climate change in Thua Thien Hue Province (Binh et al. 2016), Phu Vang coastal district (Fig. 1) was selected to conduct the survey. The district is located on the depressed estuary plain of the Huong River Basin, with around 10,351 ha of agricultural land mixed with aquaculture ponds, accounting for $48.4 \%$ of the total natural land area.

Agriculture-related livelihoods such as breeding, farming, fishing, and aquaculture are the mainstay of the local economy but are facing many challenges from both the ocean (typhoons, storms, sea-level rise, saline intrusion) and from the river (floods and droughts) (Binh et al. 2016; Thuc et al. 2008). The 1999 historic flood, as an example, washed away 64 houses to the sea and took many lives. Besides, the unseasonable, sudden, and torrential rains during summer in 2010, 2012, and 2013 caused substantial damage to local agricultural production. Farmers, in many other cases, had to harvest early aquaculture products such as shrimp and fish due

Table 1 The scenario of temperature and precipitation compared to the period 1986-2005; Source: Ministry of Natural Resources and Environment (Thuc et al. 2016)

\begin{tabular}{|c|c|c|c|c|c|c|}
\hline \multirow{2}{*}{$\begin{array}{l}\text { Climatic charac- } \\
\text { teristics }\end{array}$} & \multirow{2}{*}{$\begin{array}{l}\text { RCP4.5 scenarios } \\
2016-2035\end{array}$} & \multicolumn{5}{|c|}{ RCP8.5 scenarios } \\
\hline & & 2046-2065 & 2080-2099 & 2016-2035 & $2046-2065$ & 2080-2099 \\
\hline \multicolumn{7}{|l|}{ (a) Annual } \\
\hline $\begin{array}{l}\text { Temperature } \\
\left({ }^{\circ} \mathrm{C}\right)\end{array}$ & 0.7 & 1.4 & 1.9 & 0.8 & 1.9 & 3.3 \\
\hline Precipitation $(\%)$ & 17.0 & 22.5 & 26.2 & 16.5 & 18.6 & 21.2 \\
\hline \multicolumn{7}{|l|}{ (b) Seasonal } \\
\hline \multicolumn{7}{|l|}{ Temperature $\left({ }^{\circ} \mathrm{C}\right)$} \\
\hline Summer & 0.7 & 1.7 & 2.4 & 0.9 & 2.2 & 3.8 \\
\hline Winter & 0.7 & 1.2 & 1.4 & 0.8 & 1.6 & 2.8 \\
\hline \multicolumn{7}{|l|}{ Precipitation (\%) } \\
\hline Summer & 2.0 & 3.7 & -9.6 & 13.7 & 0.5 & 5.9 \\
\hline Winter & 9.1 & 21.8 & 26.7 & 9.8 & 7.4 & 26.6 \\
\hline
\end{tabular}




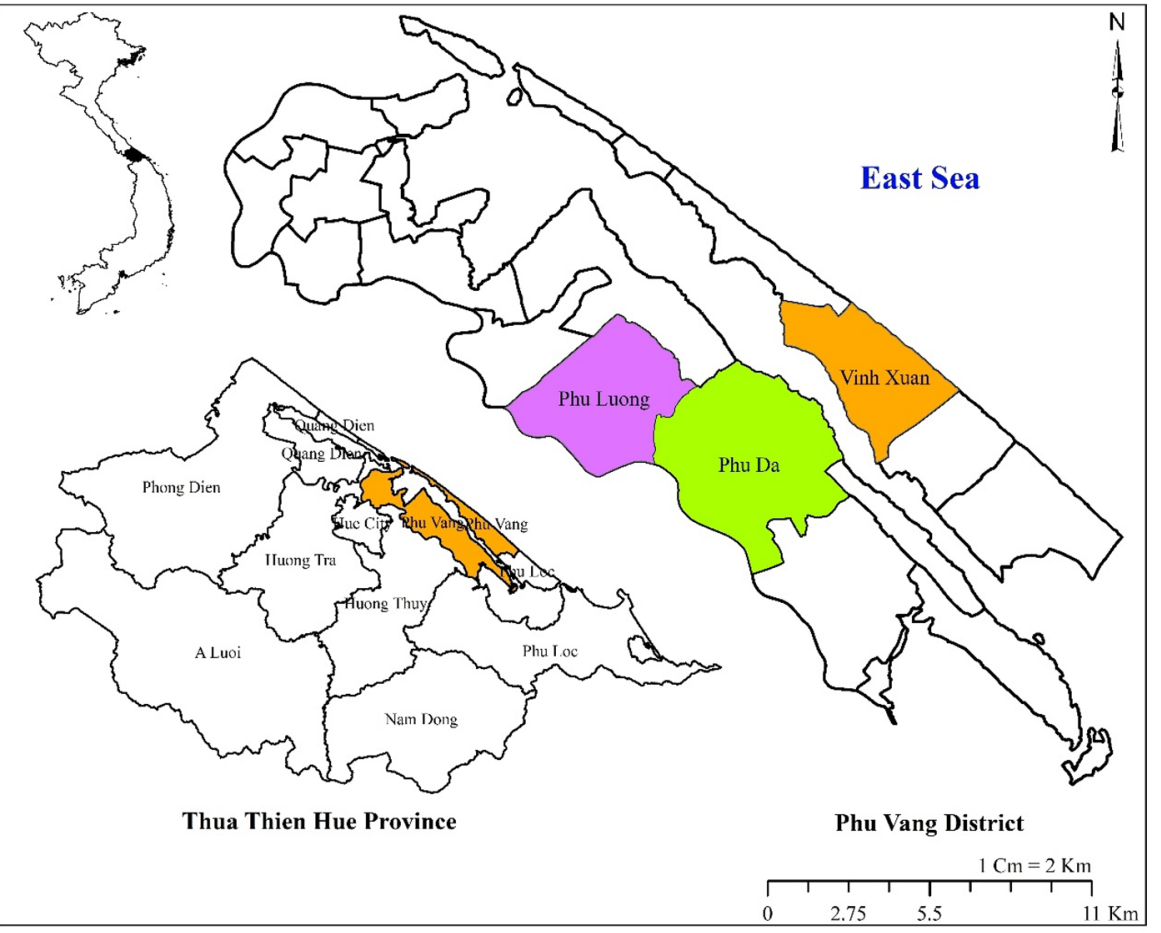

Fig. 1 Map of the study site; Source: Authors

to the outbreak of diseases, which severely reduces economic efficiency (Ngoan et al. 2013). Drought and salinity intrusion, based on climate change scenarios, are expected to increase in this area. Also, the downward trend of the average annual rainfall over the past decade is an obvious danger to the local agriculture.

\subsection{Data collection}

A field survey was carried out in October 2018 in three communes belonging to Phu Vang coastal district, more specifically Phu Luong, Phu Da, and Vinh Xuan. These communes were selected based on their vulnerability to climate change as explained by the person responsible for agriculture and rural development in the locality. To estimate the appropriate sample size for analyzing, this study applied Slovin's formula as shown below:

$$
n=\frac{N}{1+N e^{2}}
$$

where $n$ : sample size, $N$ : total population $(6,000$ households), $e$ : marginal error $(10 \%)$. 
According to the 2016 rural census data in Quang Dien district, there were about 6000 small-scale farming households out of 12,087 households working in the agriculture-related field, including cultivation, forestry, and aquaculture. In addition, the value of the marginal error was set at $10 \%$ due to time and financial constraints. Inserting these values $(N=6000 ; e=10 \%)$ into the above formula, with a $95 \%$ confidence level, a survey sample $(n)$ higher than 98 is acceptable. Therefore, the cross-sectional data of 110 households in the three aforementioned communes were collected using the face-to-face interview method. While the number of households surveyed in Phu Luong and Phu Da was both 40, that in Vinh Xuan was only 30 due to time constraints. To facilitate the survey, a semi-structured questionnaire was prepared after an elaborate process of document review in combination with the consultation of experts, who are well versed in both the local natural conditions and local people's livelihoods. The respondents were randomly selected from the official household lists provided by the villages' head. Since the subject of this study was smallholder farmers, only farmer households with less than 0.5 hectares of farmland were visited. The heads of household were the first priority for the interview due to their crucial role in making decisions but were sometimes replaced by a second influential member to compensate for their absence in the time conducting the survey. The semi-structured questionnaire included four main sections: (1) household characteristics (age, educational background, number of labors, main livelihood activities, farming experience, access to credit, and income level); (2) involvement in community organizations; (3) perception of climate change; and (4) climate change adaptation measures.

\subsection{Methods}

This study applied the quantitative approach using a binary logit model to analyze various factors influencing the farmers' decision in implementing adaptation measures to extreme weather events in agricultural production. The general equation of a binary logit model is viewed as follows:

$$
Y=\operatorname{Ln} \frac{P(X)}{[1-P(X)]}=\beta_{0}+\beta_{1} * X_{1}+\beta_{2} * X_{2}+\beta_{3} * X_{3}+\ldots \ldots \ldots \ldots \ldots \ldots \ldots \ldots \ldots+\beta_{n} * X_{n},
$$

where, $Y$ : the dependent variable of the model indicating farmers' adaptation decision, $X_{1}, X_{2}, X_{3} \ldots, X_{\mathrm{n}}$ : explanatory variables inserted into the model for testing, $\beta_{1}$, $\beta_{2}, \beta_{3} \ldots, \beta_{\mathrm{n}}$ : regression coefficients, $\beta_{0}$ : intercept.

Farmers' adaptation decision, the dependent variable of the model, was measured as a binary variable with either 0 or 1 value. Specifically, one (1) denotes farmers who adapted to climate change by taking at least one proposed measure in their agricultural production. Conversely, zero (0) expresses farmers who did not adapt to climate change. In this study, we inserted ten explanatory variables into the binary logistic model, which either relate to socio-economic and demographic characteristics of farmer households, or their perceptions of climate change to estimate their effects on the adaptation decision. These explanatory variables were selected based on the process of literature review on climate change adaptation conducted in developing 
countries. Accordingly, the household's head basic characteristics such as gender, educational level, and farming experience were reported to affect adaptation in agricultural production (Mishra and Pede 2017; Thoai et al. 2018; Thanh 2016). Additionally, the factors related to household resources such as the number of labors, income level, nonfarm income, access to credit were also found to be associated with farmers' adaptation decisions (Deressa et al. 2009; Uy et al. 2015). Besides, the important role of factors related to the perception of climate change was also confirmed through its contributions to adaptation of farmers (Dang et al. 2014; Luu et al. 2019).

The descriptive statistics of the explanatory variables are briefly described in Table 2. The male household heads accounted for more than two-thirds (67.3\%) of the total sample. Up to $38.2 \%$ of those interviewed just attended primary school, meanwhile, only $13.6 \%$ reached the undergraduate level. Most household heads $(89.1 \%)$ experienced from 20 to 40 years in agriculture. Regarding household characteristics, more than half of households $(57.3 \%)$ had between two and five labors, while about one-third (31.8\%) just had less than three labors. The monthly per capita income was around 4.25 VND million, of which $36.3 \%$ was derived from non-agricultural activities. In addition, about one-third of those interviewed (30.9\%) had access to preferential credit supported by the local government.

Regarding the involvement in community organizations, since most households were a member of at least one group, only those actively involved in these groups were counted. This information was primarily determined based on the regular participation of members in the organization activities, and was further confirmed by the village heads. Accordingly, $40 \%$ of those surveyed were classified as actively involved in community organizations. Similarly, the perception of climate change was only considered in two aspects including climate change severity and adaptation measure efficacy since most participants perceived at least one climate-related change. As a result, $55.5 \%$ of informants confirmed the considerable impact of extreme climatic phenomena on their agricultural production, while around $60 \%$ strongly believed in the efficacy of adaptation measures in reducing risks.

In relation to these above explanatory variables, some variables related to socio-economic and demographic characteristics, such as gender, education level, farming experience, number of labors, and income level are expected to positively affect the households' adaptation decision. The implementation of adaptation measures is also assumed to be promoted by access to formal credit supported by the local government. Similarly, active involvement in the local-level community organizations, such as farmer's group, women's group, youth group, and village board is also believed to significantly contribute to the farmers' adaptation decisions. The cognitive-related factors such as perception of climate change severity and adaptation measure efficacy were also hypothesized to positively affect the farmers' adaptation decision. 


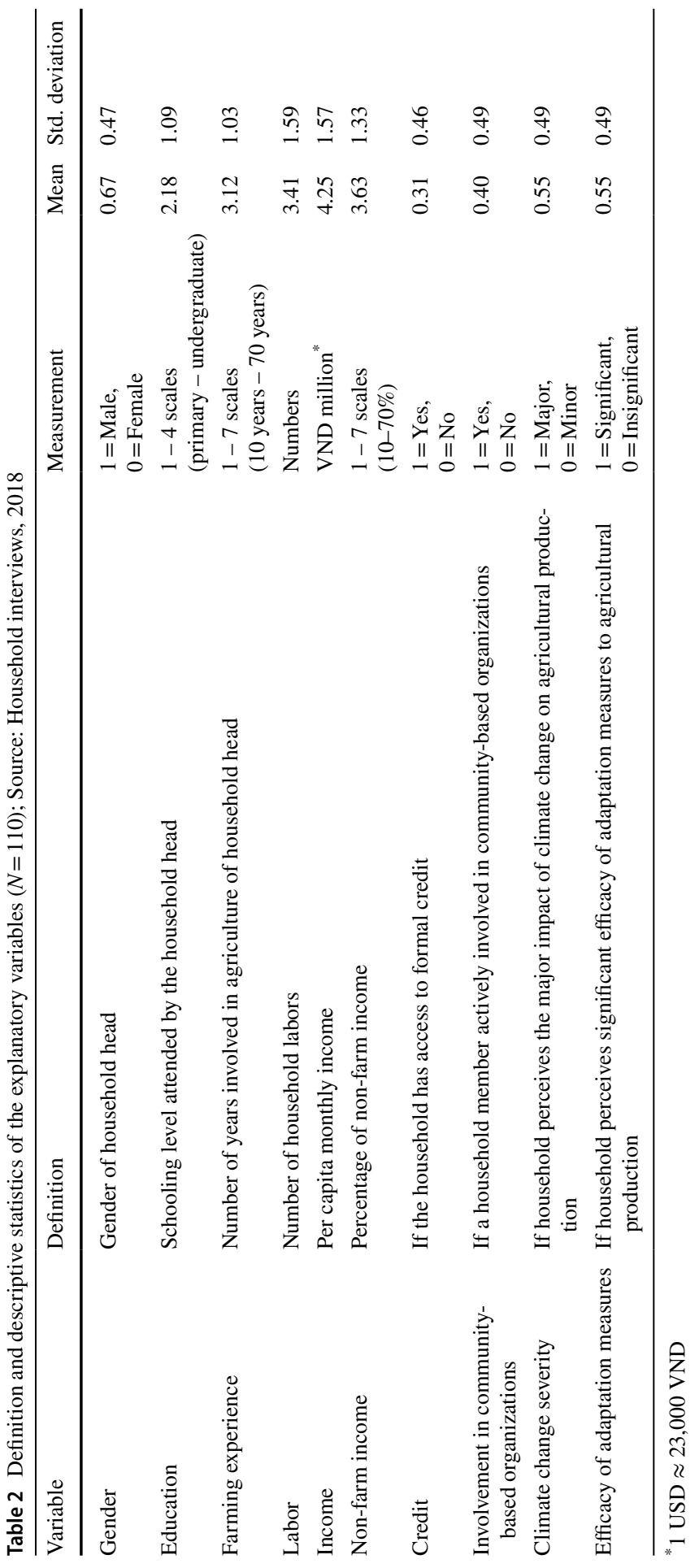




\section{Results and discussions}

\subsection{Farmers' perception of changes in climate characteristics}

To understand changes in the local climate, the interviewees were asked about whether they have perceived any changes in temperature, precipitation, typhoon, flood, and saline intrusion in the past 10 years. The results are summarized in Table 3.

The change in annual temperature was pointed out by $80.91 \%$ of respondents. Among them, most $(75.45 \%)$ perceived the increase in the annual temperature. Of which, more than a quarter (26.36\%) visibly felt the rise of temperature over the past 10 years.

The rise of temperature is a notable trend in the Summer-Autumn crop, which was confirmed by nearly $80 \%$ of the study population. Meanwhile, more than half of the respondents $(60.9 \%)$ reported the normality of temperature in the Winter-Spring crop. Conversely, about one-fifth of those interviewed $(23.64 \%)$ believed that the temperature tends to increase in the mentioned season. Besides, several farmers further stated that the dry season seems to come earlier, and the high temperature lasts longer in comparison with the previous. The exactness in farmers' perception of temperature trends was confirmed by collating with the actual temperature data collected over the past decade. In fact, the temperature data recorded in Phu Vang district indicated an upward trend in both the Summer-Autumn crop and Winter-Spring crops in the past decade (see Appendix: Figs. A1, A2, A3).

In terms of precipitation, farmers basically perceived a downward trend. Of the study population, $72.73 \%$ noted the decrease in annual rainfall, of which up to $32.73 \%$ affirmed a substantial degree. Only $19.09 \%$ of informants felt stable. In addition, the decline of precipitation in both main crops was reported by $43.6 \%$ and

Table 3 Farmers' perception of changes in climate characteristics $(N=110)$; Source: Household interviews, 2018

\begin{tabular}{|c|c|c|c|c|c|}
\hline \multirow[t]{2}{*}{ Climatic characteristics } & \multicolumn{5}{|c|}{ Percentage of respondents } \\
\hline & $\begin{array}{l}\text { Sig- } \\
\text { nificantly } \\
\text { decrease }\end{array}$ & Slightly decrease & No change & Slightly increase & $\begin{array}{l}\text { Sig- } \\
\text { nificantly } \\
\text { increase }\end{array}$ \\
\hline \multicolumn{6}{|l|}{ Temperature } \\
\hline Annual & 0.00 & 5.45 & 19.09 & 49.09 & 26.36 \\
\hline Summer-Autumn crop & 0.00 & 8.18 & 13.64 & 35.45 & 42.73 \\
\hline Winter-Spring crop & 4.54 & 10.91 & 60.91 & 20.00 & 3.64 \\
\hline \multicolumn{6}{|l|}{ Precipitation } \\
\hline Annual & 32.73 & 40.00 & 19.09 & 4.54 & 3.64 \\
\hline Summer-Autumn crop & 10.91 & 32.73 & 43.64 & 11.82 & 0.90 \\
\hline Winter-Spring crop & 40.91 & 37.27 & 13.64 & 6.36 & 1.82 \\
\hline \multicolumn{6}{|c|}{ Typhoon, flood, and saline intrusion } \\
\hline Typhoon & 1.82 & 6.36 & 13.64 & 55.45 & 22.73 \\
\hline Flood & 24.54 & 41.82 & 20.00 & 10.00 & 3.64 \\
\hline Saline intrusion & 0.00 & 0.00 & 61.82 & 30.91 & 7.27 \\
\hline
\end{tabular}


$78.2 \%$ of participants, respectively. Farmers' perception of the changes in precipitation, in general, is consistent with the data observed by the provincial hydro-meteorological center (see Appendix: Figs. A4, A5, A6).

Relating to other extreme phenomena, the majority of respondents $(78.2 \%)$ perceived the rise of typhoons, while $66.3 \%$ of them emphasized the decline of floods. However, despite the downward trend of floods, some households still complained about the increasing irregularity of floods in recent years, which makes anticipating by conventional approaches less effective. This may be an inevitable consequence of the increasing popularity of the massive dam systems in Thua Thien Hue Province. Currently, up to 62 reservoirs targeting both hydroelectricity and irrigation are being operated throughout the province. Regarding the saline intrusion, normal status was affirmed by the majority of the study population (61.82\%). More than one-third $(38.18 \%)$ of farmers, however, stressed the increasing aggravation of this phenomenon in the recent decade.

\subsection{Farmers' climate change adaptation measures}

To alleviate the adverse impacts of climate change on agriculture production, some adaptation measures were implemented by farmers. The details are briefly shown in Fig. 2. Of the total 110 respondents, 51 farmers (46.4\%) adopted at least one adaptation measure, while the remaining $53.6 \%$ were indifferent to this disturbing reality. In the study site, the most popular adaptation measures were (1) change plant varieties, (2) farming calendar adjustment, (3) crop diversification, (4) livestock diversification, (5) irrigation improvement, and (6) soil quality intensification.

Changing plant varieties were the most common adaptation measure, which was applied by $40.91 \%$ of the study population. The popularity of this measure may be due to its low cost and simplicity. Besides, each plant variety often has its own preeminent characteristics, which are suitable for different extreme weather conditions. Farmers, therefore, also have various options to solve their problems. In the last few years, some rice varieties such as Khang Dan, 18, and HT1 were predominant in the study site. However, long-time cultivation leads these varieties to be less

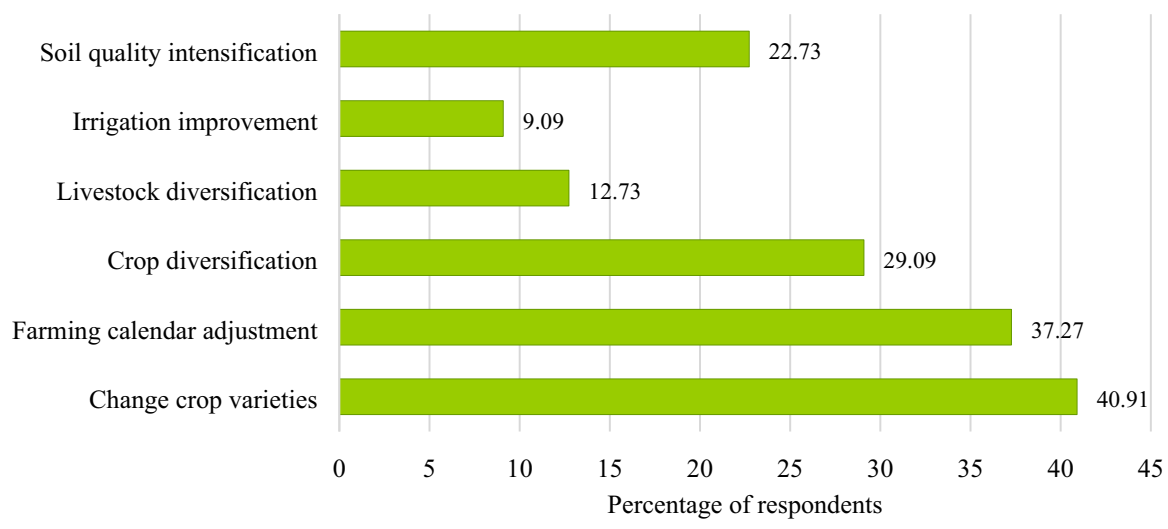

Fig. 2 Percentage of adaptation measures $(N=110)$; Source: Household interviews, 2018 
resistance and low productivity, especially under the effects of extreme conditions such as drought, saline intrusion, or pests. As a result, they have been replaced by others, which were assessed both higher productivity and better resistance to environmental changes. Besides, a shorter growing time was also an advantage of these varieties to avoid the effects of floods.

The second most widespread adaptation measure was the adjustment of farming calendars, which was confirmed by $37.27 \%$ of informants. In Phu Vang, there are two main crops including the Winter-Spring crop lasting from December to April, and the Summer-Autumn crop lasting from May to August. Generally, the seasonal calendars in the research site are planned by the local Department of Agricultural and Rural Development. However, these plans were elastically applied in farming practices. In other words, farmers can adjust their seasonal calendar in a certain range to avoid potential negative impacts from the environment, such as drought or early flood. This measure, although not costly, often requires a long-standing experience in agriculture and a profound understanding of indigenous knowledge in weather forecasting.

Besides, the diversification of crops and livestock, which was implemented by $29.09 \%$ and $12.73 \%$ of farmer households, respectively, was also chosen to reduce the risks in rice cultivation. In addition to rice cultivation, farmers often convert a part of rice land to other crops. In addition, making use of garden land to diversify agricultural production is also useful to reduce dependence on rice cultivation. Producing straw mushrooms has become a widespread trend in the locality because it can take advantage of the small home garden as well as the available rice straw after the harvest season. According to farmers, in the context of climate variation, the diversification of crop and livestock is a wise choice to reduce the risks of crop failure.

Similarly, improving irrigation and soil quality was also focused by farmers, but less popular than the others. Of the study population, there was only $9.09 \%$ of farmers who purchased pumps to be more active in irrigation. The over-reliance on available irrigation water supplied by the massive dam systems in Thua Thien Hue Province may be the root cause for the sparsity of this measure. Improving soil quality by increasing fertilizer was also applied by farmers as a way to enhance the resistance of crop to extreme weather conditions. However, due to the high cost, this measure was only carried out by nearly a quarter $(22.73 \%)$ of interviewed households.

\subsection{Factors affecting the farmers' adaptation decision}

The binary logistic model was used to investigate the factors affecting the adaptation decision of farmers. The farmers' adaptation decision is a discrete variable, which only takes either 0 or 1 . One (1) denotes the farmers who adapted to climate change, while zero (0) denotes farmers who did not adapt to climate change. Ten variables were also included in the model as predictors.

Table 4 shows that the model predicts correctly 56 out of 59 farmers (94.9\%) who did not implement any adaptation measures. Similarly, of the 51 respondents who adopted at least one adaptation measures, the model estimates wrong in 5 cases equivalent to an accuracy rate of $92 \%$. The average successful prediction percentage of the model, therefore, reaches $92.7 \%$, demonstrating high reliability. 
Table 4 The correct prediction percentage of the binary logit model; Source: Data calculated by authors, 2018

\begin{tabular}{|c|c|c|c|}
\hline \multirow[t]{2}{*}{ Observed } & \multicolumn{2}{|l|}{ Predicted } & \multirow{2}{*}{$\begin{array}{l}\text { Percent- } \\
\text { age } \\
\text { correct }\end{array}$} \\
\hline & Non-adapted & Adapted & \\
\hline Non-adapted & 56 & 3 & 94.9 \\
\hline Adapted & 5 & 46 & 90.2 \\
\hline Overall percentage & & & 92.7 \\
\hline
\end{tabular}

The estimated parameters of the binary logit model are shown in Table 5. The data first confirm the rationality of the overall relationship between explanatory variables and farmer adaptation probability $\left(\chi^{2}=99.290 ; p=0.000\right)$. The value of Nagelkerke $R$ square $(0.794)$ further indicates that the explanatory variables presented in the model explained $79.4 \%$ of the probability that farmers would adapt to climate change.

Through model results, factors driving the farmers' adaptation decision were revealed. Of the ten explanatory variables inserted, there were seven ones positively affecting the farmer adaptation probability. These included gender, education level, number of labors, per capita income, involvement in community organizations, climate change severity, and adaptation measure efficacy. Adaptation probability, in contrast, was negatively influenced by non-farm income, while completely unconnected with access to formal credit (Table 5).

The logistic regression equation can be briefly shown as follows:

$$
\begin{aligned}
\mathrm{Y}= & -9.80+1.66 * \mathrm{X}_{1}+1.01 * \mathrm{X}_{2}+0.61 * \mathrm{X}_{3}+0.579 * \mathrm{X}_{4}+0.696 * \mathrm{X}_{5}-0.091 * \mathrm{X}_{6} \\
& +0.782 * \mathrm{X}_{7}+2.12 * \mathrm{X}_{8}+2.61 * \mathrm{X}_{9}+1.45 * \mathrm{X}_{10}
\end{aligned}
$$

Table 5 Estimated result of the binary logit model on farmers' adaptation decision; Source: Data calcu-

\begin{tabular}{|c|c|c|c|c|c|c|}
\hline Indicator & $B$ & S.E & Wald & $d f$ & Sig & $\operatorname{Exp}(B)$ \\
\hline Gender** & 1.66 & 0.865 & 3.701 & 1 & 0.054 & 5.276 \\
\hline Education** & 1.01 & 0.399 & 6.461 & 1 & 0.011 & 2.755 \\
\hline Farming experience & 0.61 & 0.453 & 1.788 & 1 & 0.181 & 1.832 \\
\hline Labor** & 0.579 & 0.278 & 4.350 & 1 & 0.037 & 1.784 \\
\hline Income $* *$ & 0.696 & 0.312 & 4.987 & 1 & 0.026 & 2.007 \\
\hline Non-farm income $* * *$ & -0.091 & 0.035 & 6.701 & 1 & 0.010 & 0.913 \\
\hline Credit & 0.782 & 1.016 & 0.593 & 1 & 0.441 & 2.186 \\
\hline Involvement in local organizations*** & 2.12 & 0.784 & 7.306 & 1 & 0.007 & 8.323 \\
\hline Climate change severity** & 2.61 & 1.045 & 6.212 & 1 & 0.013 & 13.528 \\
\hline Efficacy of adaptation measures* & 1.45 & 0.802 & 3.264 & 1 & 0.071 & 4.261 \\
\hline Constant & -9.80 & 3.490 & 7.882 & 1 & 0.005 & 0.000 \\
\hline$-2 \log$ likelihood & 52.620 & & & & & \\
\hline Cox and Snell $R$ square & 0.595 & & & & & \\
\hline Nagelkerke $R$ square & 0.794 & & & & & \\
\hline Chi-square & 99.290 & & & & & \\
\hline Sig & 0.000 & & & & & \\
\hline
\end{tabular}
lated by authors, 2018

$*, * *, * * *$ denote the statistical significance at $10 \%, 5 \%$, and $1 \%$ levels, respectively 
Gender positively affected the adaptation decision at the 5\% significance level $(B=1.663, p=0.054)$. Accordingly, the men's household heads were 5.28 times more likely to adapt to climate change than women $(\mathrm{OR}=5.276)$. This is consistent with those of Thoai et al. (2018), Thanh (2016), Asrat and Simane (2018), and Mogomotsi et al. (2020), who found that female-headed households are less likely to employ adaptation strategies to improve agricultural productivity although they tend to be more vulnerable to the adverse effects of climate variations. Asrat and Simane (2018) asserted that women-headed households are commonly constrained because they are responsible for both agricultural and housewife activities. They have fewer opportunities to access information and other socio-economic resources, while they bear more family burdens than males. Besides, the delaying of female-head households in responding to climate change may also derive from their inferior economic status compared to male counterparts, as highlighted by Arora-Jonsson (2011). In the context of Vietnam, although farming is irrespective of gender, men are normally viewed as a pillar of this hard work. They are usually the most powerful in the household decision-making process and often more assertive in adjusting production activities. Men, especially in rural society, also have more opportunities to engage in recreational activities, where they can be benefited from the sharing of information, knowledge, experience related to farm work. Their adaptation intention, thereby, can be fostered.

In addition, educational level also positively affected households' adaptation in practice at the $5 \%$ significance level $(B=1.013, p=0.011)$. For every extra schooling level achieved by the head, the household's probability of adaptation will increase by nearly 2.76 times $(\mathrm{OR}=2.755)$. This correlation concurs well with previous findings that a higher educational qualification increases the probability of adaptation to climate change (Deressa et al. 2009; Thoai et al. 2018; Ndamani and Watanabe 2016). Thoai et al. (2018) found that farmers who obtain higher qualifications are more likely to adapt to climate change by switching to new cultivars and following up weather forecasts. Meanwhile, Ndamani and Watanabe (2016) suggest that better educated farmers are more knowledgeable due to their ability to access information pertaining to climate change and adaptation options. It can be argued that being better educated, in addition to raising perception and attitude to climate-related risks, is also the key to approach appropriate farming practices.

Farmers' adaptation decision was also found to be positively influenced by their own labor force $(B=0.579, p=0.037)$. Households with more labor were more likely to adapt to climate-related risks. When everything else remains constant, the adaptation odds of households will increase by $78.4 \%$ for each additional labor $(\mathrm{OR}=1.784)$. This finding, although similar to the results of Ndamani and Watanabe (2016) and Asrat and Simane (2018), in contrast with ones reported by Thoai et al. (2018) that the adaptation to climate variations is unassociated with the availability of labor. The role of labor is emphasized by Asrat and Simane (2018) through the household size because it is generally associated with a better labor endowment. Labor is an indispensable resource for income earning, especially in countries with low-mechanized agriculture like Vietnam. Lack of labor, therefore, can be a major obstacle for households to adjust production activities such as diversifying crops and livestock. Besides, financial-related pressure stemming from the labor shortages may also be a barrier preventing households from adopting costly measures such as 
improving soil quality and irrigation. This is a probable reason why the income also impacted the households' adaptation $(B=0.696, p=0.026, \mathrm{OR}=2.007)$. The reality is that lower income households often prioritize their meager income to maintain a basic living standard rather than investing in adaptation measures. In other words, they are almost passive despite noticing the potential effects of climate change. Their agricultural production efficiency, therefore, is largely entrusted to natural conditions. Similar relationships were figured out by Ndamani and Watanabe (2016) and Al-amin et al. (2020) that household income is an important factor encouraging adaptation or the willingness to pay for the adaptation program.

The percentage of non-farm income, meanwhile, negatively impacted the household's adaptation. A higher percentage of non-farm income earned by farmers, a lower adaptation probability in agriculture were $(B=-0.091, p=0.01)$. The adaptation odds of households will decrease by $8.7 \%$ for each additional $10 \%$ increase in the percentage of non-farm income $(\mathrm{OR}=0.913)$. This connection, nevertheless, is discord with those found by Deressa et al. (2009) and Asrat and Simane (2018). Deressa et al. (2009) concluded that the non-farm income increases the likelihood of adopting various adaptation options such as switching new cultivars, changing seasonal calendar, or intensifying irrigation. Asrat and Simane (2018), meanwhile, claimed that income from these sources empowers farmers to adopt costly measures. Improving income by engaging in non-farm activities such as peddling, bricklayer, motorcycle-taxi, or hired labor is relatively common in the study site. These works, though temporary, have significantly contributed to the total income of households, especially in the off-farm season. However, over-focusing on non-farm activities may lead households to neglect farming due to time constraints. Some households asserted that making money from off-farm employment is not only easier and quicker but also less risky than farming ones. Thereby, the role of agriculture in the household's income structure is gradually becoming non-essential. This implies that implementing adaptation measures is currently unregardful by some farmers.

The adaptation decision to climate change was also found to be positively affected by the involvement in community organizations $(B=2.119 ; p=0.007)$. Accordingly, the farmers who actively involved in community organizations were 8.32 times more likely to adapt to climate change in practice $(\mathrm{OR}=8.323)$. Besides promoting social activities, the local community organizations are also environments for members to help each other in improving livelihoods. By regularly participating in the activities of community organizations, farmers may be able to access useful information, knowledge, skills, and resources, which potentially promote their adaptation in reality. Indeed, by engaging in these groups, farmers have opportunities to observe adaptation choices from the other members before applying. This could enhance farmers' belief about the adaptation practices and increase the adoption probability (Khanal et al. 2019). This result, however, differs from those of Thoai et al. (2018), and Piya et al. (2013) that membership in local organizations has a negligible influence on the adaptation to climate change of farmers. In addition to demographic and socio-economic characteristics, the farmers' adaptation was further identified to be influenced by cognitive factors. The farmers, who perceived the major impact of climate change on agricultural production $(B=2.605 ; p=0.013 ; \mathrm{OR}=13.528)$, or the significant efficacy of adaptation measures $(B=1.449 ; p=0.071 ; \mathrm{OR}=4.261)$ were more likely to adapt to climate change. These 
findings are in line with earlier conclusions of Dang et al. (2014) and Luu et al. (2019) that farmers are more likely to adapt to climate change when they perceive higher risks to their farming and greater effectiveness of adaptation measures.

Farming experience and access to credit, meanwhile, were entirely separated from the household adaptation probability. These results, even though differing from some published studies of Tessema et al. (2017), Nhemachena and Hassan (2008), and Ndamani and Watanabe (2016), are consistent with those of Piya et al. (2013). A possible reason is that farmers access to credit to mainly fulfill their subsistence needs instead of investing in improving production.

\section{Conclusions and policy implications}

Vietnam agriculture is characterized by small-scale farmers who are viewed as the most susceptible in the context of climate change. In the long term, adaptation is probably a sustainable approach to alleviate potential adverse effects. Since adaptation is a local-specific issue, understanding households' constraints in adaptation is a prerequisite to propose incentive solutions. This study, therefore, was carried out with the primary aim of examining the determinants of smallholder farmers' adaptation decision to climate change in the central coast region of Vietnam.

The results first indicated that changes in climatic phenomena in the recent decade were accurately perceived by the majority of the study population. In an effort to alleviate the potential risks, nearly half of the farmer households actively adapted to these uncertainties by blending various measures. Less costly measures, including changing crop varieties, adjusting farming calendar, diversifying crops, were much preferred. Meanwhile, costlier ones such as diversifying livestock, improving irrigation, and intensifying soil quality were less concerned. This reality, on one hand, displays the financial-related pressures of farmers in selecting adaptation measures but may also imply the doubtfulness of farmers on risk-reducing effectiveness of adaptation measures.

The findings from the binary logit model, meanwhile, exposed potential factors driving farmers' adaptation decision. The role of gender in adaptation was first confirmed by a positive correlation. Female-headed households appear to be more vulnerable in the context of changing climate due to their less active in performing adaptation measures. Considering gender differences, therefore, should be taken into account in the design of supporting policies. In relation to knowledge, the educational level of the household heads was more helpful than their farming experience in anticipating household adaptation, which was obviously expressed through their positive linkage. This may be due to the positive effects of formal learning on farmers' attitudes towards climate change, which should be seen as an important ground leading them to the adaptation decision.

Labor shortages and low earnings, which is often conjoined with poverty, were also found as significant obstacles holding back farmers' adaptive efforts. The connection between them seems like a vicious cycle. While poverty reduces the probability of adaptation, delays in responding to climate change, in turn, can make poverty worse. Therefore, incorporating adaptive support policies with ones related to poverty reduction is requisite to break out this endless cycle. The non-farm income, 
contrary to expectations, adversely influenced farmers' adaptation in practice. The increasing penetration of non-farm occupations with relatively attractive earnings, which is likely to make farmers underestimating their traditional agricultural production, was considered the root cause of this anxious reality.

Besides the aforementioned demographic characteristics, households' adaptation probability was also found to be promoted by actively involved in the local community-based organizations. These local organizations, apart from their own missions, can be viewed as an ideal place to exchange knowledge, experience related to climate change. Farmers' attitudes, thereby, may be reinforced to direct them to adaptation decisions. This argument is further reinforced since the proper understanding of climate change severity and the effectiveness of adaptation also appeared as factors increasing adaptation probability. This result implies that raising perception on climate change should be integrated as an inseparable component during designing incentive adaptation policies. Access to the official loans, meanwhile, was entirely unattached to the farmers' adaptation decisions. The inefficiency in the management of loan capital was primarily attributed to this unexpected outcome.

From these above findings, disseminating information on the potential adverse effects of climate change and the meaning of interventions should be foremost prioritized in encouraging farmers' adaptation. Additionally, since the education level of farmers is basically low, this information should be conveyed simply and understandably to most farmers, especially focusing on those who are female, or less educated. Together with using the mass media, such duty should be carried out through the local community-based organizations to intensify the persuasion and degree of spread. Besides, since actively involved in community-based organizations increases the adaptation probability, more attention should be paid to the activities of these organizations to make them more attractive to members. Since the high percentage of non-farm income diminish adaptation motivation, over-focusing on this sector should be avoided. In other words, the involvement in the non-agricultural sector to improve the earnings should be done simultaneously with the adaptation process in agriculture to ensure the sustainability of rural society. Finally, policymakers should design preferential loans to facilitate the adaptation process of modest income or fewer labor households. The funding provided, however, should be strictly managed in combination with appropriate adaptation guidance to avoid inefficiency due to the misuse of beneficiaries.

\section{Compliance with ethical standards}

Conflict of interest The authors declare that they have no conflict of interest.

Open Access This article is licensed under a Creative Commons Attribution 4.0 International License, which permits use, sharing, adaptation, distribution and reproduction in any medium or format, as long as you give appropriate credit to the original author(s) and the source, provide a link to the Creative Commons licence, and indicate if changes were made. The images or other third party material in this article are included in the article's Creative Commons licence, unless indicated otherwise in a credit line to the material. If material is not included in the article's Creative Commons licence and your intended use is not permitted by statutory regulation or exceeds the permitted use, you will need to obtain permission directly from the copyright holder. To view a copy of this licence, visit http://creativecommons.org/licen ses/by/4.0/. 


\section{Appendix}

See Figs. A1, A2, A3, A4, A5, A6, and A7.

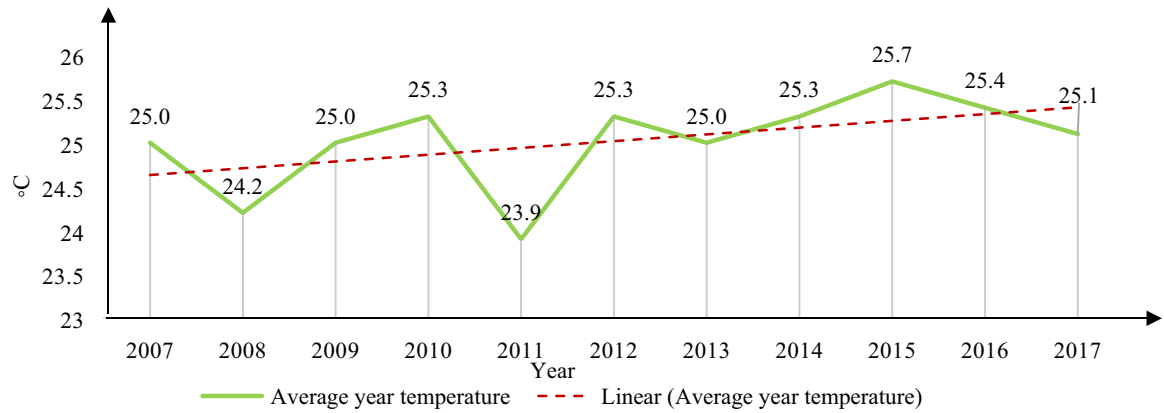

Fig. A1 Annual temperature trend over 10 years' period in Phu Vang district; Source: Thua Thien Hue Meteorological office, 2018

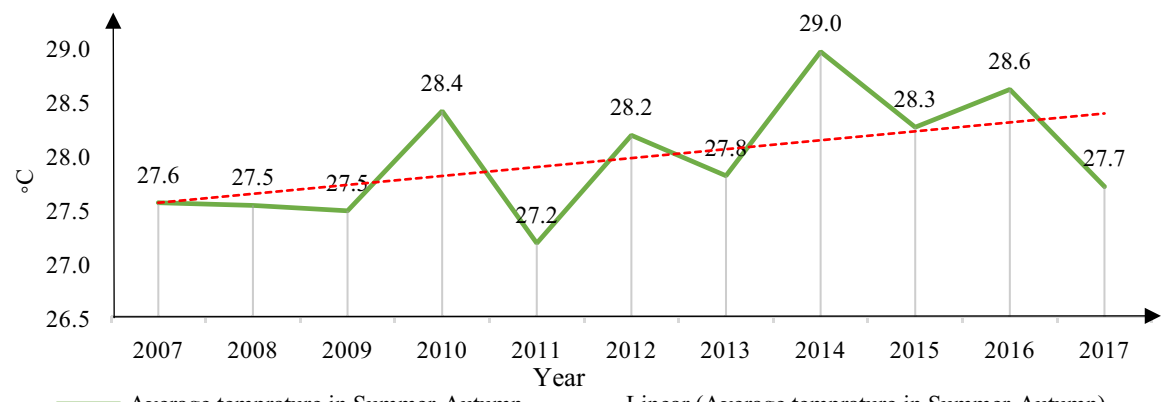

Fig. A2 Average temperature trend in Summer-Autumn crop in Phu Vang district; Source: Thua Thien Hue Meteorological office, 2018

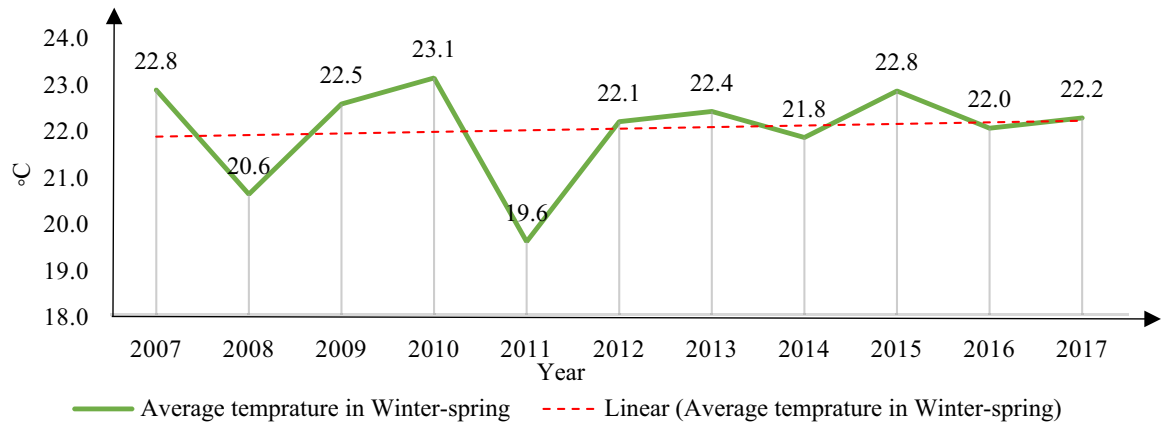

Fig. A3 Average temperature trend in Winter-Spring crop in Phu Vang district; Source: Thua Thien Hue Meteorological office, 2018 


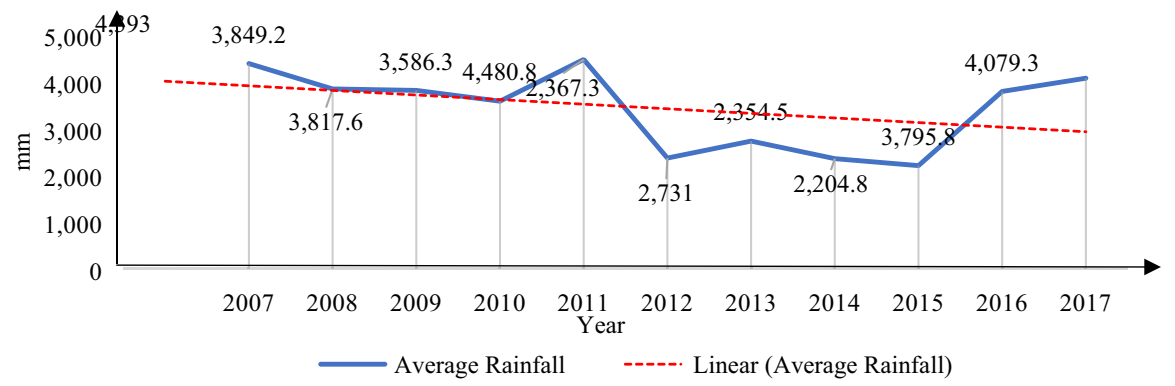

Fig. A4 Annual precipitation over ten years in Phu Vang district (mm); Source: Thua Thien Hue Meteorological office, 2018

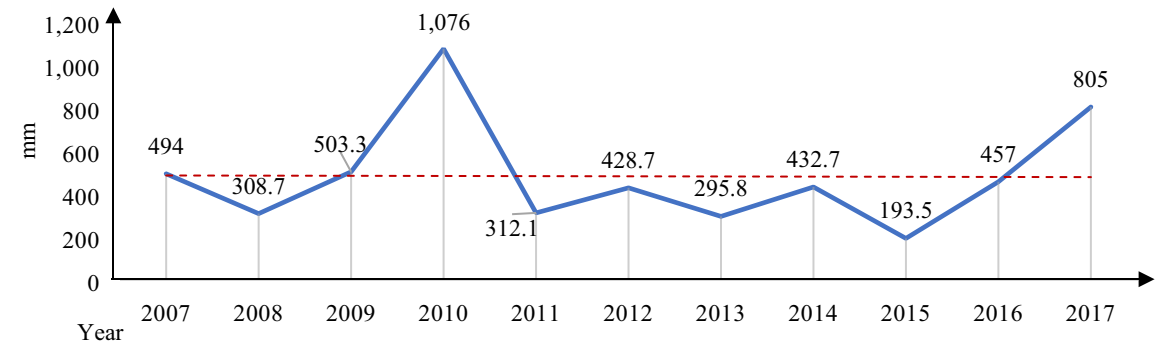

- Average precipitation of Summer-Autumn crop - - - Linear (Average precipitation of Summer-Autumn crop)

Fig. A5 Average precipitation trend in Summer-Autumn crop in Phu Vang district (mm); Source: Thua Thien Hue Meteorological office, 2018

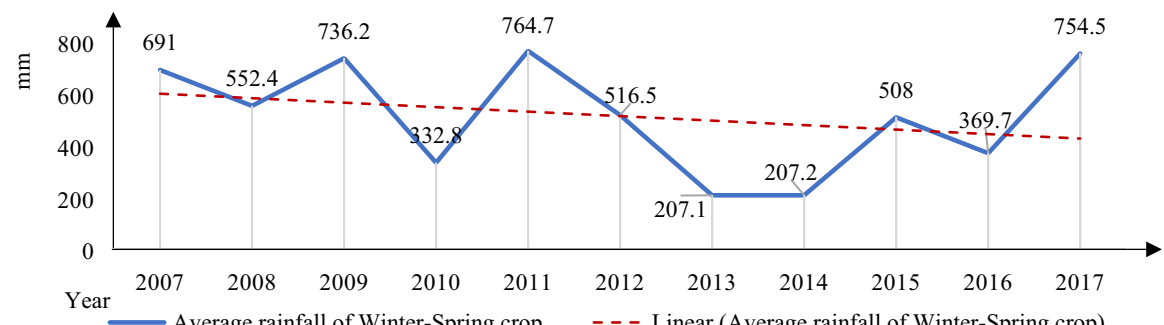

Fig. A6 Average precipitation trend in Winter-Spring crop in Phu Vang district (mm); Source: Thua Thien Hue Meteorological office, 2018 


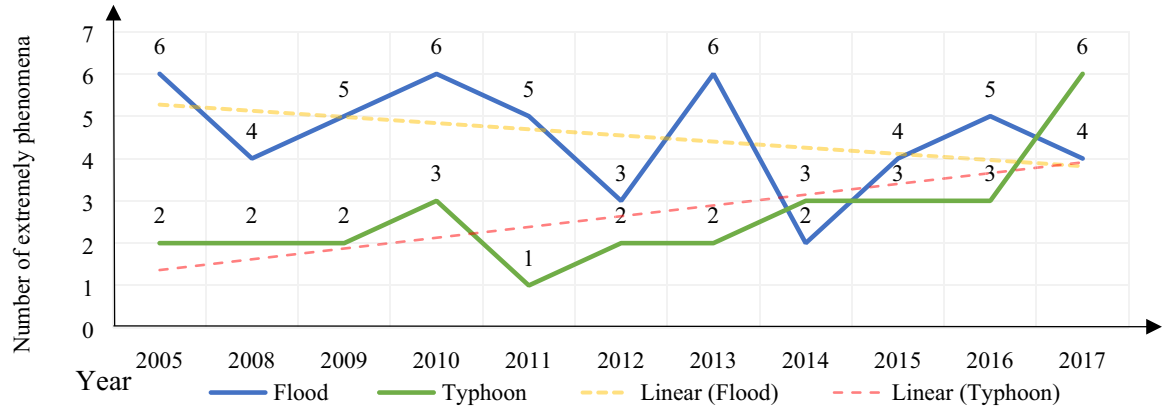

Fig. A7 Number of extremely phenomena occurred in Phu Vang district 2007-2017; Source: Thua Thien Hue Meteorological office, 2018

\section{References}

Al-amin AQ, Masud MM, Sarkar SKMD, Filho WL, Doberstein B (2020) Analysing the socioeconomic and motivational factors affecting the willingness to pay for climate change adaptation in Malaysia. Int J Disaster Risk Reduct. https://doi.org/10.1016/j.ijdrr.2020.101708

Alam GMM, Alam K, Mushtaq S (2017) Climate risk management climate change perceptions and local adaptation strategies of hazard-prone rural households in Bangladesh. Clim Risk Manag. https://doi. org/10.1016/j.crm.2017.06.006

Arora-Jonsson S (2011) Virtue and vulnerability: discourses on women, gender and climate change. Glob Environ Chang 21(2):744-751. https://doi.org/10.1016/j.gloenvcha.2011.01.005

Asrat P, Simane B (2018) Farmers' perception of climate change and adaptation strategies in the dabus watershed. North-West Ethiopia Ecol Process 7(7):1-13. https://doi.org/10.1186/s13717-018-0118-8

Bakhsh K, Kamran MA (2019) Adaptation to climate change in rain-fed farming system in Punjab. Pakistan Int J Commons 13(2):833-847. https://doi.org/10.5334/ijc.887

Bankoff G (1999) A history of poverty: the politics of natural disasters in the Philippines, 1985-95. Pacific Rev 12(3):381-420. https://doi.org/10.1080/09512749908719297

Berchum ECV, Corven TAWV, Hessels TM, Kuijk D, Oosten JV, Zorgdrager A (2014) The framework for integrated water management in the Thua Thien-Hue Province. Delft University of Technology. https://research.tudelft.nl/en/publications/the-framework-for-integrated-water-management-in-theth ua-thien-h. Accessed 19 Apr 2020

Binh MN, An LV, Thuy NTT, Giang NTH, Hoai HTT, Dan TV (2016) Impact of climate change on aquaculture in Phu Vang District, Thua Thien Hue Province, Vietnam. SEARCA Agriculture and Development Discussion Paper Series

Bryan E, Deressa TT, Gbetibouo GA, Ringler C (2009) Adaptation to climate change in Ethiopia and South Africa : options and constraints. Environ Sci Policy 12:413-426. https://doi.org/10.1016/j. envsci.2008.11.002

Coumou D, Rahmstorf S (2012) A decade of weather extremes. Nat Clim Chang 2(7):491-496. https:// doi.org/10.1038/nclimate1452

Dang HL, Li E, Nuberg I, Bruwer J (2014) Understanding farmers' adaptation intention to climate change: a structural equation modelling study in the Mekong Delta, Vietnam. Environ Sci Policy 41:11-22. https://doi.org/10.1016/j.envsci.2014.04.002

Deressa TT, Hassan MR, Ringler C, Alemu T, Yesuf M (2009) Determinants of farmers' choice of adaptation methods to climate change in the Nile Basin of Ethiopia. Glob Environ Chang 19:248-255. https:// doi.org/10.1016/j.gloenvcha.2009.01.002

Eckstein D, Hutfils M-L, Winges M (2019) Global climate risk index 2019 - who suffers most from extreme weather events? weather-related loss events in 2017 and 1998 to 2017. Germanwatch e.V. https://germa nwatch.org/en/16046\#: :text=The\%20most\%20recent\%20data\%20available,Honduras\%20and\%20Mya nmar\%20rank\%20highest. Accessed 4 June 2020

Fortier F (2010) Taking a climate chance: a procedural Critique of Vietnam's climate change strategy. Asia Pac Viewp 51(3):229-247. https://doi.org/10.1111/j.1467-8373.2010.01428.x 
Fussel HM, Klein RJT (2006) Climate change vulnerability assessments: an evolution of conceptual thinking. Clim Change 75(3):301-329. https://doi.org/10.1007/s10584-006-0329-3

Gbetibouo GA, Hassan RM, Ringler C (2010) Modelling farmers' adaptation strategies for climate change and variability: the case of the Limpopo Basin. South Africa Agrekon 49(2):217-234. https://doi. org/10.1080/03031853.2010.491294

Grothmann T, Patt A (2005) Adaptive capacity and human cognition: the process of individual adaptation to climate change. Glob Environ Chang 15:199-213. https://doi.org/10.1016/j.gloenvcha.2005.01.002

GSO (2018) Statistical yearbook of Vietnam 2017. Statistical publishing house, Hanoi. https://www.gso.gov. vn/wp-content/uploads/2019/10/Nien-giam-2017-pdf.pdf. Accessed 19 Feb 2020

Hatfield JL, Boote KJ, Kimball BA, Ziska LH, Izaurralde RC, Ort DR et al (2011) Climate impacts on agriculture: implications for crop production. Agron J 103(2):351-370. https://doi.org/10.2134/agronj2010 .0303

Hisali E, Birungi P, Buyinza F (2011) Adaptation to climate change in Uganda: evidence from micro level data. Glob Environ Chang 21(4):1245-1261. https://doi.org/10.1016/j.gloenvcha.2011.07.005

Ho TT, Shimada K (2019) The effects of climate smart agriculture and climate change adaptation on the technical efficiency of rice farming - an empirical study in the Mekong Delta of Vietnam. Agric. https ://doi.org/10.3390/agriculture9050099

Irish Aid (2017) Vietnam climate action report for 2016. https://www.climatelearningplatform.org/vietn am-country-climate-action-report-2016. Accessed 26 June 2020

IPCC (2018) Summary for policymakers. In: Global warming of $1.5^{\circ} \mathrm{C}$. An IPCC special report on the impacts of global warming of $1.5^{\circ} \mathrm{C}$ above pre-industrial levels and related global greenhouse gas emission pathways, in the context of strengthening the global response To. https://www.ipcc.ch/site/ assets/uploads/sites/2/2019/05/SR15_SPM_version_report_LR.pdf

IPPC (2013) Climate change 2013: the physical science basis. Contribution of working group I to the fifth assessment report of the intergovernmental panel on climate change. Cambridge University Press, Cambridge, UK and New York, NY, USA. https://doi.org/10.1017/CBO9781107415324

IPCC (2014) Climate change 2014. Synthesis report. IPCC, Geneva

Kebede Y, Gunjal K, Coffin G (1990) Adoption of new technologies in ethiopian agriculture: the case of Tegulet-Bulga District Shoa Province. Agric Econ 4(1):27-43. https://doi.org/10.1016/01695150(90)90018-V

Khanal U, Wilson C, Hoang VN, Lee B (2019) Impact of community-based organizations on climate change adaptation in agriculture: empirical evidence from Nepal. Environ Dev Sustain 21(2):621-635. https:// doi.org/10.1007/s10668-017-0050-6

Luu TA, Nguyen AT, Trinh QA, Pham VT, Le BB, Nguyen DT et al (2019) Farmers' intention to climate change adaptation in agriculture in the Red River Delta Biosphere Reserve (Vietnam): a combination of Structural Equation Modeling (SEM) and Protection Motivation Theory (PMT). Sustain. https://doi. org/10.3390/su11102993

Menike LMCS, Arachchi KAGPK (2016) Adaptation to climate change by smallholder farmers in rural communities: evidence from Sri Lanka. Ital Oral Surg 6:288-292. https://doi.org/10.1016/j.profo o.2016.02.057

Mideksa TK (2010) Economic and distributional impacts of climate change: the case of Ethiopia. Glob Environ Chang 20(2):278-286. https://doi.org/10.1016/j.gloenvcha.2009.11.007

Mishra AK, Pede VO (2017) Perception of climate change and adaptation strategies in Vietnam: Are there intra-household gender differences? Int J Clim Chang Strateg Manag 7(3):394-417. https://doi. org/10.1108/IJCCSM-01-2017-0014

Mogomotsi PK, Sekelemani A, Mogomotsi GEJ (2020) Climate change adaptation strategies of small-scale farmers in Ngamiland East, Botswana. Clim Change 159(3):441-460. https://doi.org/10.1007/s1058 4-019-02645-w

MONRE (2009) Climate change and sea level rise scenarios for Vietnam. https://www.preventionweb.net/ files/11348_ClimateChangeSeaLevelScenariosforVi.pdf. Accessed 4 May 2020

Nam PK (2011) Social capital and private adaptation to climate change: evidence from the Mekong River Delta in Vietnam. Econ Adapt to Clim Chang http://www2.gwu.edu/ iiep/adaptation/docs/Nam, Social Capital and Private Adaptation to Climate Change Evidence from the Mekong River Delta in Vietnam. pdf.

Ndamani F, Watanabe T (2016) Determinants of farmers' adaptation to climate change: a micro level analysis in Ghana. Scientia Agricola 73(3):201-208. https://doi.org/10.1590/0103-9016-2015-0163

Nelson GC, Rosegrant MW, Koo J, Robertson R, Sulser T, Zhu T et al (2009) Climate change: impact on agriculture and costs of adaptation. International Food Policy Research Institute, Washington 
Ngoan LD, Thi L, Sen H, Thi N, Huong T, Christoplos I, et al (2013) Climate change and rural institutions in central Vietnam. DIIS working paper 2013:14. https://www.files.ethz.ch/isn/174296/WP2013-14_ CCRI_VietNam_lili_ich_web.pdf. Accessed 1 Apr 2020

Nhemachena C, Hassan R (2008) Micro-level analysis of farmers' adaptation to climate change in southern Africa. In: IFPRI Discussion Paper No. 00714. International Food Policy Research Institute, Washington, DC. http://ebrary.ifpri.org/cdm/ref/collection/p15738coll2/id/39726. Accessed 25 Mar 2020

Parry M, Rosenzweig C, Livermore M (2005) Climate change, global food supply and risk of Hunger. Philos Trans R Soc B 360(1463):2125-2138. https://doi.org/10.1098/rstb.2005.1751

Patt AG, Schro D (2008) Perceptions of climate risk in Mozambique : implications for the success of adaptation strategies. Glob Environ Chang 18:458-467. https://doi.org/10.1016/j.gloenvcha.2008.04.002

Piya L, Maharjan KL, Joshi NP (2013) Determinants of adaptation practices to climate change by Chepang households in the rural mid-hills of Nepal. Reg Environ Chang 13(2):437-447. https://doi.org/10.1007/ s10113-012-0359-5

Shiferaw B, Holden ST (1998) Resource degradation and adoption of land conservation technologies in the Ethiopian Highlands: a case study in Andit Tid, North Shewa. Agric Econ 18(3):233-247. https://doi. org/10.1111/j.1574-0862.1998.tb00502.x

Simane B, Zaitchik BF, Folzt JD (2016) Agroecosystem specific climate vulnerability analysis: application of the livelihood vulnerability index to a tropical highland region. Mitig Adapt Strateg Glob Chang 21:39-65. https://doi.org/10.1007/s11027-014-9568-1

Suu LTT, My PTD, Bubeck P, Douma A (2010) Community-based adaptation strategies for enhancing resilience to climate change in the Huong River Basin. CSRD study report. http://www.adapts.nl/perch/ resources/communitybased-adaptation-strategies-for-enhancing-resilience-to-climate-change-in-thehuong-river-basin.pdf. Accessed 12 Apr 2020

Tenge AJ, De Graaff J, Hella JP (2004) Social and economic factors affecting the adoption of soil and water conservation in West Usambara Highlands, Tanzania. L Degrad Dev 15(2):99-114. https://doi. org/10.1002/ldr.606

Tesfaye W, Seifu L (2016) Climate change perception and choice of adaptation strategies empirical evidence from Smallholder Farmers. Int J Clim Chang Strateg Manag 8(2):252-270. https://doi.org/10.1108/ IJCCSM-01-2014-0017

Tessema YA, Patt A, Joerin J (2017) Factor affecting smallholder farmers' adaptation to climate change through non-tachnological adjustment. Environ Dev. https://doi.org/10.1016/j.envdev.2017.11.001

Thanh QN (2016) Farmers adaptive measures to climate change induced natural shocks through past climate experiences in the Mekong River Delta, Vietnam. African J Agric Res 11(15):1361-1372. https://doi. org/10.5897/ajar2015.10756

Thoai TQ, Rañola RF, Camacho LD, Simelton E (2018) Determinants of farmers' adaptation to climate change in agricultural production in the central region of Vietnam. Land Use Policy 70:224-231. https ://doi.org/10.1016/j.landusepol.2017.10.023

Thuc T, Thang NV, Huong HTL, Khiem MV, Hien NX, Phong DH (2016) Climate change and sea level rise scenarios for Vietnam - summary for policymakers, ministry of natural resources and environment. http://www.imh.ac.vn/files/doc/2017/CCS\%20final.compressed.pdf. Accessed 4 July 2020

Thuc T, Tuong LN, Hieu NT, Kien TM, Tuyen HM, Thinh DQ et al (2008) Climate change impacts in Huong River Basin and adaptation in its Coastal District Phu Vang, Thua Thien Hue Province. https:// www.cakex.org/sites/default/files/documents/NCAP.VN_.CON-01.FinalReport.final_.pdf. Accessed 27 Apr 2020

Tran P, Shaw R, Chantry G, Norton J (2008) GIS and local knowledge in disaster management: a case study of flood risk mapping in Thua Thien Hue Province, Vietnam. Disaster 33(1):152-169. https://doi.org/1 0.1111/j.0361-3666.2008.01067.x

Uddin MN, Bokelmann W, Entsminger JS (2014) Factors affecting farmers' adaptation strategies to environmental degradation and climate change effects: a farm level study in Bangladesh. Climate 2(4):223241. https://doi.org/10.3390/cli2040223

Uy TC, Limnirankul B, Chaovanapoonphol Y (2015) Factors impact on farmers' adaptation to drought in maize production in highland area of central Vietnam. Agric Agric Sci Procedia 5:75-82. https://doi. org/10.1016/j.aaspro.2015.08.011

Vedwan N, Rhoades RE (2001) Climate change in the western Himalayas of India : a study of local perception and response. Clim Res 19(2):109-117

Waibel H, Pahlisch TH, Völker M (2018) Farmers' perceptions of and adaptations to climate change in southeast Asia: the case study from Thailand and Vietnam. Clim Smart Agric Nat Resour Manag Policy 52:137-160. https://doi.org/10.1007/978-3-319-61194-5_7 
World Bank (2016) The world bank annual report 2016. Washington, DC. https://openknowledge.worldbank. org/handle/10986/24985. Accessed 12 Mar 2020

WTO (2018) World trade statistical review 2018. https://www.wto.org/english/res_e/statis_e/wts2018_e/ wts2018_e.pdf. Accessed 19 Feb 2020

Yu B, Zhu T, Breisinger C, Hai NM (2010) Impacts of climate change on agriculture and policy options for adaptation. The case of Vietnam. IFPRI discussion paper 01015. https://reliefweb.int/sites/reliefweb.int/ files/resources/A06030A0F205087E4925777C001E6988-Full_Report.pdf. Accessed 17 Feb 2020

Publisher's Note Springer Nature remains neutral with regard to jurisdictional claims in published maps and institutional affiliations.

\section{Affiliations}

\section{Hoang Ha Vo ${ }^{1} \cdot$ Takeshi Mizunoya $^{2}$ (D) Cong Dinh Nguyen ${ }^{1,3}$}

Hoang Ha Vo

vhha@hce.edu.vn

Cong Dinh Nguyen

ncdinh@hce.edu.vn

1 Faculty of Economics and Development Studies, University of Economics, Hue University, Hue, Vietnam

2 Faculty of Life and Environmental Sciences, University of Tsukuba, Tsukuba, Japan

3 Graduate School of Environmental and Life Science, Okayama University, Okayama, Japan 